\title{
Individual electrical conductivity test for the assessment of soybean seed germination
}

\section{Teste de condutividade elétrica individual para estimativa da germinação em sementes de soja}

\author{
Nilson Matheus Mattioni ${ }^{1 *}$; Liliane Marcia Mertz²; Ana Paula Piccinin Barbieri³; \\ Fernando Machado Haesbaert ${ }^{4}$; Willian Giordani ${ }^{5}$; Sidinei José Lopes ${ }^{1}$
}

\begin{abstract}
Soybean seed quality is affected by many factors, which may occur during the production, processing, and storage phases. To ensure the quality of seeds, the adoption of fast and efficient methods to estimate seed viability in quality control programs is important. This study aimed to determine a partition point of the individual electrical conductivity test to predict soybean seed germination. Three lots each of five different soybean cultivars (Fundacep 57 RR, BMX Potência RR, BMX Força RR, BMX Turbo RR, and Nidera $7321 \mathrm{RG}$ ) were used. Seed quality was assessed through the mass of 1,000 seeds (MTS), moisture content $(\mathrm{MC})$, germination test $(\mathrm{G})$, bulk electrical conductivity (BEC), individual electrical conductivity (IEC), accelerated ageing (AA), and field seedling emergence (FSE). To determine a partition point in the IEC test for predicting germination, seeds were subjected to the germination test in the same position used for the IEC test. The accuracy of the partition point was tested by comparing predicted germination with the standard germination test. The partition point obtained for normal seeds was $130 \mu \mathrm{S} . \mathrm{cm}^{-1} . \mathrm{seed}^{-1}$. The IEC test, however, had limitations in predicting soybean seed germination. The data for predicted germination were different from those obtained by the standard test, because the characteristics of each lot led to differences in the electrical conductivity values.
\end{abstract}

Key words: Glycine $\max$ (L.) Merrill, partition point, fast test, seed quality

\section{Resumo}

A qualidade das sementes de soja pode ser afetada por inúmeros fatores que podem ocorrer em qualquer etapa da produção. Para garantir a qualidade das sementes é necessária a adoção testes rápidos e eficientes em estimar a viabilidade das sementes. O objetivo desse estudo foi determinar o ponto de partição do teste de condutividade elétrica individual (CEI) para estimar a germinação de sementes de soja. Foram utilizados 15 lotes pertencentes a diferentes cultivares (Fundacep 57 RR, BMX Potência RR, BMX Força RR, BMX Turbo RR, e Nidera 7321 RG). A caracterização dos lotes foi efetuada pelo peso de mil sementes, teor de água, germinação, condutividade elétrica massal e individual, envelhecimento acelerado e emergência a campo. Para determinação do ponto de partição as sementes foram submetidas ao teste padrão de germinação, respeitando-se a posição utilizada na leitura da CEI. A veracidade do

${ }^{1}$ Eng $^{{ }^{\text {s }}} \mathrm{Agr}^{\mathrm{os}_{\mathrm{s}}}$, Drs., Dept ${ }^{\mathrm{o}}$ de Fitotecnia, Universidade Federal de Santa Maria, UFSM, Santa Maria, RS, Brasil. E-mail: nilsonmattioni@gmail.com; sjlopes@pq.cnpq.br

${ }^{2}$ Eng $^{\mathrm{a}}$ Agr ${ }^{\mathrm{a}}$, Dr ${ }^{\mathrm{a}}$ Pesquisadora EMBRAPA Soja, Londrina, PR, Brasil. E-mail: lilianemertz@yahoo.com.br

${ }^{3}$ Eng $^{\mathrm{a}}$ Agr ${ }^{\mathrm{a}}$, Dr ${ }^{\mathrm{a}}$ EMATER-RS/ASCAR, Santa Maria, RS. E-mail: apaulabarbieri@yahoo.com.br

${ }^{4}$ Eng $^{\mathrm{O}}$ Agr $^{\mathrm{o}}$, Discente do Curso de Doutorado em Agronomia, PPGAGRO, UFSM, Santa Maria, RS, Brasil. E-mail: fhaesbaert@ gmail.com

5 Discente do Curso de Graduação em Agronomia, Universidade do Estado de Santa Catariana, UDESC, Lages, SC, Brasil. E-mail: giordani.willian@yahoo.com.br

* Author for correspondence 
ponto de partição foi testada através de comparação entre a germinação estimada e a obtida no teste padrão. O ponto de partição da CEI é $130 \mu \mathrm{S} . \mathrm{cm}^{-1}$.semente ${ }^{-1}$. Entretanto o método mostrou limitação em estimar a germinação de sementes de soja. Características de cada lote influenciaram na CEI levando a diferenças entre a germinação estimada e o teste padrão.

Palavras-chave: Glycine $\max (\mathrm{L}$.) Merrill, ponto de partição, teste rápido, qualidade de sementes

\section{Introduction}

The use of high quality seeds is an important factor to increase yield, since fast and uniform emergence of seedlings is an essential condition for establishing a suitable plant stand in the field (SCHUCH; KOLCHINSKI; FINATTO, 2009). Many factors can affect seed quality, such as those occurring in the field or during other phases of seed production, including harvest, drying, processing, and storage (BRACCINI et al., 2003; MARCONDES; MIGLIORANZA; FONSECA, 2005). Therefore, the adoption of a seed quality control system that can be meticulously applied in all production phases is needed to ensure the production of high quality seeds.

Seed quality control for marketing purposes is based on the germination test, which is efficient in at least two aspects: it provides information on the germination potential of a given seed sample under the optimal conditions, and is a standardized test. A disadvantage of the germination test, however, is the delay in providing results, thus making necessary the development of fast and efficient tests for predicting soybean seed viability.

The electrical conductivity test was developed by Fick and Hibbard (1925) and has been recommended to evaluate seed vigor based on the cellular membrane organization, in several species such as pea (AOSA, 2002; COSTA et al., 2008), soybean (DIAS; MARCOS FILHO, 1996; VIEIRA et al., 2002), castor bean (SOUZA et al., 2009), onion (DIAS et al., 2006), and squash seeds (DUTRA; VIEIRA, 2006). Before harvest, temporary structural disorganization occurs in the cell membranes during the seed drying period. Therefore, during the soaking process, seeds need to reorganize their cellular membrane system and repair damage that might have occurred (BEWLEY; BLACK, 1994). During this process, the seed releases sugars, amino acids, fatty acids, enzymes, and ions in different quantities, which may vary according to the organizational state of the cellular membrane system. Seeds with low physiological quality have a reduced capacity for membrane reorganization and, consequently, higher amounts of solutes lixiviate into the imbibition solution, thus resulting in a reduction in germination uniformity and germination speed (VIEIRA et al., 2002).

The electrical conductivity test is usually conducted through the bulk method. Recently, however, new equipment has been developed to allow the measurement of electrical conductivity in a single seed (STEERE; LEVENGOOG; BONDIE, 1981; HAMMAN; HALMAJAN; EGLI, 2001). Thus, it is nowadays possible to determine the partition point of the individual electrical conductivity test to separate viable seeds and predict their germination percentage. However, the currently available results suggest that more biological investigation is necessary to characterize the relationship between individual seed conductivity and germination before this test can be used routinely in the laboratory.

Therefore, the aim of this study was to determine the partition point of the individual electrical conductivity test to estimate the germination of soybean seeds.

\section{Material and Methods}

Three commercial soybean seed lots, from five different soybean cultivars, i.e. Fundacep 57 RR, BMX Potência RR, BMX Força RR, BMX Turbo $R R$, and Nidera $7321 \mathrm{RG}$, totaling 15 lots of seeds, 
were used in the experimental work. The initial moisture content of the seeds was homogenous and around $13 \%$ for all seed lots.

The seed quality of the different lots was assessed using the following tests:

Germination test $(\mathrm{G})$ : performed with four replications of 100 seeds each, for each seed lot. For this, seeds were sown on top of two sheets of paper towel, covered with another sheet of the same paper and moistened with sterile distilled water in an amount equivalent to 2.5 times the mass of dry substrate, made into rolls and then placed into a seed germinator at $25^{\circ} \mathrm{C}$ (BRASIL, 2009). Germination counts were performed on the fifth and eighth days after sowing. Normal seedlings were assessed according to the Rules for Seed Analysis and the results are expressed as a percentage (BRASIL, 2009).

Bulk electrical conductivity (BEC): for this test, four replications of 50 seeds each were used. Seeds were weighed with the aid of a $0.001 \mathrm{~g}$ precision balance and then soaked in $50 \mathrm{ml}$ deionized water for $24 \mathrm{~h}$ at $25^{\circ} \mathrm{C}$. The electrical conductivity of the solution was determined using a conductivimeter (DIGIMED DM-31) and data are expressed as $\mu \mathrm{S}$ .cm $\mathrm{cm}^{-1} \cdot \mathrm{g}^{-1}$.

Individual electrical conductivity (IEC): this test was performed with four replications of 100 seeds each using the SAD 9000-S (Consultar) apparatus that determines the conductivity of individual seeds. Seeds were placed into trays containing 100 individual cells, and one seed $+6.0 \mathrm{ml}$ of deionized water were added into each cell. Seeds displaying visibly damaged seed coats were replaced and the trays were then incubated in a seed germinator at $25^{\circ} \mathrm{C}$ for $24 \mathrm{~h}$. After this period, the electrical conductivity was determined for each individual seed. To determine the partition point of the IEC for the estimation of germination percentage, seeds were subjected to the germination test in the same position used in the standard IEC test. Evaluations were performed and seedlings were sorted as normal, abnormal, or dead seeds. A correlation between the values of electrical conductivity obtained for each seed and the seedling structure (normal, abnormal, or dead seed) was then performed.

Accelerated aging test (AA): this test was performed by using four replications of 100 seeds each. Seeds of each replication were evenly arranged, in single layers, on top of a stainless steel screen placed in the upper part of an $11 \mathrm{~cm} \mathrm{x} 11 \mathrm{~cm} \mathrm{x}$ $3.5 \mathrm{~cm}$ transparent plastic germination box (gerbox) containing $40 \mathrm{ml}$ of distilled water, and then placed in a BOD type germinator at $41^{\circ} \mathrm{C}$ for $48 \mathrm{~h}$. After this period, seeds were subjected to the germination test, as previously described. Germination was assessed on the fifth day after sowing, and normal seedlings were assessed according to the Rules for Seed Analysis (BRASIL, 2009). Results are expressed as the percentage of normal seedlings.

Field seedling emergence (FSE): this test was performed with four replications of 100 seeds each, which were distributed along $1.0 \mathrm{~m}$ rows, with 0.5 $\mathrm{m}$ interspaces. After 14 days, no further emergence of new seedlings was observed, and thus the percentage of normal seedlings was computed.

Statistical analysis: a completely randomized experimental design was used, with four replications of 100 seeds each, for each characteristic assessed. The results of seed physiological characterization were submitted to ANOVA and correlation analyses.

Data were arcsine transformed, $(\mathbf{x} / \mathbf{1 0 0})^{1 / 2}$, to the normalize distribution. Means were compared by the Scott-Knott cluster method at 5\% probability ( $\mathrm{p}<$ 0.05) using SISVAR software (FERREIRA, 2003).

To estimate the partition point of normal, abnormal, and dead seeds, the data obtained in the electrical conductivity test were used to perform a boxplot analysis, using the third quartile as the reference. The confidence interval was computed in order to determine the minimum and maximum limits of individual electrical conductivity test in each lot. Boxplot and confidence interval analyses were performed using the R Program (2011). 


\section{Results and Discussion}

The results obtained in the assessment of seed physiological quality (Table 1) clearly revealed differences among different soybean seed lots. This variability is an important factor in assessing the efficiency of a vigor test.

Table 1. Estimated means of seed quality obtained for the mass of 1,000 seeds (MTS), standard germination test (G) $\%$, bulk electrical conductivity test (BEC), individual electrical conductivity test (IEC), accelerated aging test (AA), and field seedling emergence test (FSE) in 15 different soybean seed lots.

\begin{tabular}{ccccccc}
\hline Seed lots & $\begin{array}{c}\text { MTS } \\
(\mathrm{g})\end{array}$ & $\begin{array}{c}\mathrm{G} \\
(\%)\end{array}$ & $\begin{array}{c}\text { BEC } \\
\left(\mu \mathrm{S} . \mathrm{cm}^{-1} \cdot \mathrm{g}^{-1}\right)\end{array}$ & $\begin{array}{c}\text { IEC } \\
\left(\mu \mathrm{S} . \mathrm{cm}^{-1} \cdot \mathrm{seed}^{1}\right)\end{array}$ & $\begin{array}{c}\text { AA } \\
(\%)\end{array}$ & $\begin{array}{c}\text { FSE } \\
(\%)\end{array}$ \\
\hline 1 & $162.3 \mathrm{~b}^{*}$ & $67 \mathrm{~d}^{*}$ & $88.1 \mathrm{f}^{*}$ & $352.1 \mathrm{~d}^{*}$ & $36 \mathrm{c}^{*}$ & $42.0 \mathrm{c}^{*}$ \\
2 & $163.9 \mathrm{~b}$ & $79 \mathrm{c}$ & $80.8 \mathrm{e}$ & $329.0 \mathrm{~d}$ & $36 \mathrm{c}$ & $36.0 \mathrm{c}$ \\
3 & $162.8 \mathrm{~b}$ & $76 \mathrm{c}$ & $77.1 \mathrm{e}$ & $328.8 \mathrm{~d}$ & $34 \mathrm{c}$ & $39.0 \mathrm{c}$ \\
4 & $140.6 \mathrm{~d}$ & $98 \mathrm{a}$ & $41.8 \mathrm{~b}$ & $95.2 \mathrm{a}$ & $74 \mathrm{~b}$ & $77.0 \mathrm{a}$ \\
5 & $141.5 \mathrm{~d}$ & $93 \mathrm{~b}$ & $46.0 \mathrm{~b}$ & $109.7 \mathrm{a}$ & $74 \mathrm{~b}$ & $75.0 \mathrm{a}$ \\
6 & $118.4 \mathrm{e}$ & $95 \mathrm{a}$ & $48.9 \mathrm{~b}$ & $96.1 \mathrm{a}$ & $66 \mathrm{~b}$ & $69.0 \mathrm{~b}$ \\
7 & $146.6 \mathrm{c}$ & $83 \mathrm{c}$ & $49.1 \mathrm{~b}$ & $139.4 \mathrm{~b}$ & $80 \mathrm{~b}$ & $64.0 \mathrm{~b}$ \\
8 & $147.3 \mathrm{c}$ & $84 \mathrm{c}$ & $44.7 \mathrm{~b}$ & $141.6 \mathrm{~b}$ & $78 \mathrm{~b}$ & $67.0 \mathrm{~b}$ \\
9 & $146.2 \mathrm{c}$ & $85 \mathrm{c}$ & $55.8 \mathrm{c}$ & $148.4 \mathrm{~b}$ & $78 \mathrm{~b}$ & $70.0 \mathrm{~b}$ \\
10 & $176.1 \mathrm{a}$ & $98 \mathrm{a}$ & $31.7 \mathrm{a}$ & $128.5 \mathrm{~b}$ & $84 \mathrm{a}$ & $83.0 \mathrm{a}$ \\
11 & $175.2 \mathrm{a}$ & $90 \mathrm{~b}$ & $36.8 \mathrm{a}$ & $105.4 \mathrm{a}$ & $81 \mathrm{~b}$ & $65.0 \mathrm{~b}$ \\
12 & $175.5 \mathrm{a}$ & $96 \mathrm{a}$ & $33.8 \mathrm{a}$ & $117.0 \mathrm{a}$ & $90 \mathrm{a}$ & $64.0 \mathrm{~b}$ \\
13 & $144.5 \mathrm{c}$ & $84 \mathrm{c}$ & $71.6 \mathrm{~d}$ & $232.0 \mathrm{c}$ & $44 \mathrm{c}$ & $56.0 \mathrm{c}$ \\
14 & $145.8 \mathrm{c}$ & $91 \mathrm{~b}$ & $66.8 \mathrm{~d}$ & $259.1 \mathrm{c}$ & $35 \mathrm{c}$ & $50.0 \mathrm{c}$ \\
15 & $143.0 \mathrm{~d}$ & $89 \mathrm{~b}$ & $63.2 \mathrm{~d}$ & $248.9 \mathrm{c}$ & $37 \mathrm{c}$ & $52.0 \mathrm{c}$ \\
\hline $\bar{x}$ & 152.6 & 87 & 55.8 & 188.7 & 62 & 60.0 \\
\hline $\mathrm{CV}(\%)$ & 10.6 & 9.9 & 32.1 & 49.5 & 35.1 & 23.5 \\
\hline
\end{tabular}

*Means followed by the same letter in the columns are not statistically different by the Scott Knott test, at $5 \%$ probability $(\mathrm{p}<0.05)$. Source: Elaboration of the authors.

The germination test classified the seed lots into four categories (Table 1). The lowest germination percentage was observed for seed lot $1(67 \%$ normal seedlings). Seed lots 2, 3, 7, 8, and 13 had a germination percentage ranging from $77 \%$ to $84 \%$. For seed lots 5, 11, 14, and 15, however, the seed germination ranged between $89 \%$ and $93 \%$. For seed lots $4,6,10$, and 12 , higher seed germination rates were identified, and the percentage of normal seedlings ranged from $95 \%$ to $98 \%$.

In contrast to the germination test, the results of the field seedling emergence test classified seed lots into three categories; seed lots 4, 5 and 10 showed the greatest vigor. In addition, a large difference in the percentage of normal seedlings was detected between germination and field seedling emergence (Table 1). Since the germination test is usually conducted under optimal conditions, it is not always possible to estimate the performance of a seed lot in the field, based only on the standard germination test. According to Copeland and McDonald (2001), since the standard germination test is conducted under ideal conditions, it does not necessarily reflect the germination potential of a seed lot under field conditions.

For the other tests of vigor (accelerated ageing, bulk electrical conductivity, and individual electrical conductivity), the results were similar to those obtained for field seedling emergence. Lower vigor was obtained for lots 1, 2, 3, 13, 14 and 15. The results obtained for the mass of 1,000 seeds (Table 1) indicated that there was no influence of seed size on vigor. 
To determine the partition point of IEC for predicting germination percentage, after the assessment of IEC, the soybean seeds were subjected to the standard germination test in the same position as in the IEC test. After counting, each seedling was sorted as a normal seedling, an abnormal seedling, or a dead seed. Boxplot analysis was used to obtain the partition point for each category. IEC partition points were $130 \mu \mathrm{S} . \mathrm{cm}^{-1}$.seed ${ }^{-1}, 265 \mu \mathrm{S} . \mathrm{cm}^{-1}$.seed ${ }^{-1}$, and $460 \mu \mathrm{S} . \mathrm{cm}^{-1}$.seed ${ }^{-1}$, for normal seedlings, abnormal seedlings, and dead seeds, respectively. Different results were found by Steere, Levengoog and Bondie (1981), who used 90 microamps in the seed analyzer
Model ASA 610 to determine the difference between germinable and non-germinable seeds.

The accuracy of the data was tested by comparing the estimated germination, determined by the partition point for normal seedlings $\left(130 \mu \mathrm{S} . \mathrm{cm}^{-1}\right.$ . seed $^{-1}$ ), with the actual germination, assessed by the standard germination test. Problems associated with the usual application of the IEC in predicting soybean seed germination were detected, as differences were observed among the estimated and actual germination data, mainly in low physiological quality seed lots (Table 2).

Table 2. Means estimated for the germination percentage obtained by standard germination (SG) and estimated germination (EG) tests, using the partition point of individual electrical conductivity of $130 \mu \mathrm{S} . \mathrm{cm}^{-1} . \mathrm{seed}^{1}$ in 15 soybean seed lots.

\begin{tabular}{ccc}
\hline Lots & SG (\%) & EG (\%) \\
\hline 1 & $67 \mathrm{c}^{*}$ & $12 \mathrm{~d}^{*}$ \\
2 & $79 \mathrm{~b}$ & $20 \mathrm{~d}$ \\
3 & $77 \mathrm{~b}$ & $20 \mathrm{~d}$ \\
4 & $98 \mathrm{a}$ & $83 \mathrm{a}$ \\
5 & $93 \mathrm{a}$ & $88 \mathrm{a}$ \\
6 & $95 \mathrm{a}$ & $90 \mathrm{a}$ \\
7 & $83 \mathrm{~b}$ & $65 \mathrm{~b}$ \\
8 & $84 \mathrm{~b}$ & $72 \mathrm{~b}$ \\
9 & $85 \mathrm{~b}$ & $73 \mathrm{~b}$ \\
10 & $98 \mathrm{a}$ & $78 \mathrm{~b}$ \\
11 & $90 \mathrm{a}$ & $75 \mathrm{~b}$ \\
12 & $96 \mathrm{a}$ & $78 \mathrm{~b}$ \\
13 & $84 \mathrm{~b}$ & $39 \mathrm{c}$ \\
14 & $91 \mathrm{a}$ & $37 \mathrm{c}$ \\
15 & $89 \mathrm{a}$ & $41 \mathrm{c}$ \\
\hline
\end{tabular}

*Means followed by the same letter in the columns are not statistically different by the Scott Knott test, at $5 \%$ probability ( $\mathrm{p}<0.05$ ). Source: Elaboration of the authors.

An analysis of confidence intervals was performed, aiming to determine the maximum and minimum IEC limits for each seedling category (normal, abnormal, or dead seeds) for each seed lot (Table 3). The data for the different seed lots showed considerable differences in the values, hence confirming the limitation of this technique. For example, the electrical conductivity data for normal seedlings varied from $65.48 \mu{\mathrm{S} . \mathrm{cm}^{-1} \text {.seed }}^{-1}$ (minimum) to $210.23 \mu \mathrm{S} \cdot \mathrm{cm}^{-1} \cdot \mathrm{seed}^{-1}$ (maximum) among lots, showing that establishing a single partition point for all seed lots is not feasible (Table 3). Previous studies have already shown that several factors, such as cultivar (DIAS; MARCOS FILHO, 1996), seed storage conditions (PANOBIANCO; VIEIRA; PERECIN, 2007; ABREU et al., 2011), seed pathogens (WAIN-TASSI et al., 2012), the initial water content of seeds (VIEIRA et al., 2002), and seed physiological quality (COSTA; CARVALHO, 2006) can affect the results of the electrical conductivity test. 
Table 3. Minimum limit (Mi) and Maximum limit (Ma) for the confidence interval obtained through the test of individual electrical conductivity for normal seedlings (N), abnormal seedlings (A), and dead seeds (D) in 15 soybean seed lots.

\begin{tabular}{ccccccc}
\hline & \multicolumn{3}{c}{$\mathrm{N}$} & \multicolumn{3}{c}{$\mathrm{A}$} \\
\hline Seed & \multicolumn{3}{c}{$\mu \mathrm{cm}^{-1} . \mathrm{seed}^{-1}$} & \multicolumn{3}{c}{$\mathrm{D}$} \\
\cline { 2 - 6 } Lot & \multicolumn{1}{c}{$\mathrm{Mi}$} & $\mathrm{Ma}$ & $\mathrm{Mi}$ & $\mathrm{Ma}$ & $\mathrm{Mi}$ & $\mathrm{Ma}$ \\
\hline 1 & 179.30 & 210.23 & 259.59 & 308.82 & 386.29 & 432.07 \\
2 & 170.93 & 204.87 & 292.04 & 341.14 & 365.97 & 410.62 \\
3 & 158.79 & 184.54 & 262.58 & 315.59 & 375.10 & 421.88 \\
4 & 91.54 & 100.86 & 108.38 & 144.54 & 228.82 & 372.41 \\
5 & 79.74 & 88.11 & 81.77 & 109.76 & 173.88 & 324.21 \\
6 & 65.48 & 74.05 & 73.87 & 107.86 & 121.91 & 238.39 \\
7 & 104.75 & 118.52 & 155.13 & 193.09 & 192.97 & 276.82 \\
8 & 96.87 & 112.26 & 125.82 & 158.71 & 216.73 & 312.46 \\
9 & 97.38 & 110.04 & 149.71 & 190.57 & 202.34 & 304.22 \\
10 & 85.83 & 98.20 & 114.20 & 146.36 & 196.93 & 323.95 \\
11 & 83.74 & 97.75 & 125.47 & 160.76 & 158.21 & 277.62 \\
12 & 86.95 & 99.60 & 124.67 & 171.70 & 156.52 & 284.98 \\
13 & 125.75 & 142.46 & 160.35 & 191.28 & 262.96 & 312.14 \\
14 & 134.58 & 156.45 & 206.35 & 255.88 & 282.97 & 330.43 \\
15 & 138.50 & 163.16 & 179.43 & 223.14 & 265.19 & 318.01 \\
\hline
\end{tabular}

Source: Elaboration of the authors.

When the data shown in Figure 1 and Tables 3 are compared, it was possible to verify that the partition point for normal seedlings, abnormal seedlings, and dead seeds varied according to the physiological quality of each seed lot. Seed lots with high physiological quality showed lower values of the minimum and maximum limits for IEC when compared to seed lots with low physiological quality. This can be explained by the fact that the first signal of the deterioration process is cellular membrane disorganization, and that germination ability loss can only be detected at the end of the deterioration process. Therefore, it is doubtless possible to say that seeds that produce normal seedlings actually come from high physiological quality lots; they have greater vigor and better cellular membrane organization than seeds that come from low physiological quality seed lots. Additionally, it was possible to verify that greater variability occurred in seed lots with low physiological quality, which showed more discrepancy in the values (Table 3; Figure 2). These results agree with those of Costa and Carvalho (2006) found in a study carried out on coffee beans.

The individual electrical conductivity test has limitations in predicting the germination of soybean seeds; however, it was efficient for sorting soybean seed lots into different levels of vigor (Figure 2) and also showed similar results with the field seedling emergence test (Tables 1). 
Figure 1. Boxplot analysis to estimate the partition point for the individual electrical conductivity test (IEC), in obtaining normal seedlings (1), abnormal seedlings (2) and dead seeds (3) within soybean seed lots. Data were estimated from the results obtained from 15 soybean seed lots.

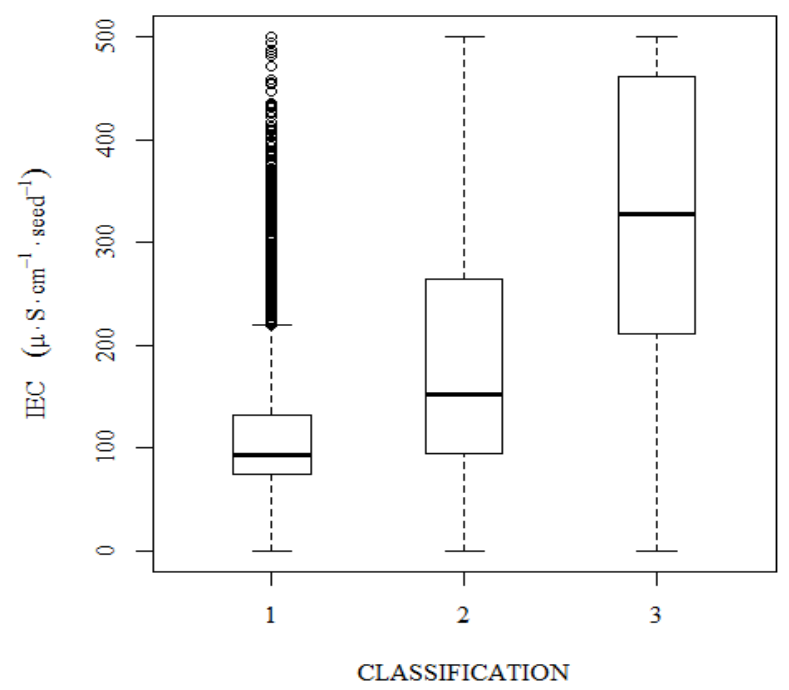

Source: Elaboration of the authors.

Figure 2. Boxplot analysis of the estimated means of the individual electrical conductivity test (IEC) in 15 soybean seed lots.

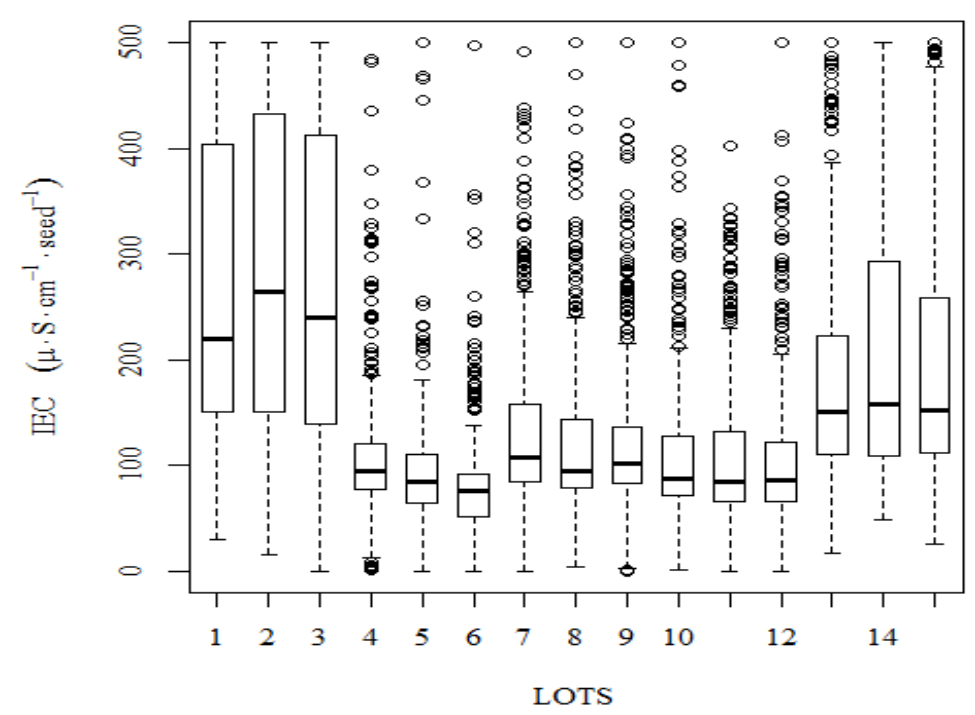

Source: Elaboration of the authors.

\section{Conclusions}

1 - The partition point obtained for normal seeds in the individual electrical conductivity test was $130 \mu \mathrm{S} . \mathrm{cm}^{-1} \cdot$ seed $^{-1}$.
2 - This technique has limitations in determining soybean seed germination because variable characteristics in each lot lead to differences in electrical conductivity values. 


\section{Acknowledgments}

The authors would like to thank FAPERGS for the financial support.

\section{References}

ABREU, L. A. S.; CARVALHO, M. L.; PINTO, C. A. G.; KATAOBA, V. Y. Teste de condutividade elétrica na avaliação de sementes de girassol armazenadas sob diferentes temperaturas. Revista Brasileira de Sementes, Brasília, v. 33, n. 4, p. 635-642, 2011.

ASSOCIATION OF OFFICIAL SEED ANALYSTS AOSA. Seed Vigor Testing Handbook. Lincoln, 2002. 105p. (Contribution, 32).

BEWLEY, J. D.; BLACK, M. Seed physiology of development and germination. New York: Plenum Press, 1994. $445 \mathrm{p}$.

BRACCINI, A. L.; MOTTA, I. S.; SCAPIM, C. A.; BRACINI, M. C. L.; ÁVILA, M. R.; SCHUAB, S. R. P. Semeadura da soja no período de safrinha: potencial fisiológico e sanidade das sementes. Revista Brasileira de Sementes, Brasília, v. 25, n. 1, p. 76-86, 2003.

BRASIL. Ministério da Agricultura, Pecuária e Abastecimento. Roles to seed analysis. Secretaria de Defesa Agropecuária. Brasília, 2009. 395 p.

COPELAND, L. O.; MCDONALD, M. B. Seed vigor and vigor testing. In: . Seed science and technology.

New York: Chapman and Hall, 2001. p. 121-144.

COSTA, C. J.; VILLELA, F. A.; BERTONCELLO, M. R.; TILLMANN, M. A. A.; MENEZES, N. L. Préhidratação de sementes de ervilha e sua interferência na avaliação do potencial fisiológico. Revista Brasileira de Sementes, Brasília, v. 30, n. 1, p. 198-207, 2008.

COSTA, P. S. C.; CARVAlho, M. L. M de. Teste de condutividade elétrica individual na avaliação da qualidade fisiológica de sementes de café (Coffea arabica L.). Ciência e Agrotecnologia, Lavras, v. 30, n. 1, p. 9296, 2006.

DIAS, D. C. F. S.; BHERING, M. C.; TOKUHISA, D.; HILST, P. C. Teste de condutividade elétrica para avaliação do vigor de sementes de cebola. Revista Brasileira de Sementes, Brasília, v. 28, n. 1, p. 154-162, 2006.

DIAS, D. C. F. S.; MARCOS FILHO, J. Testes de condutividade elétrica para avaliação do vigor de sementes de soja (Glycine $\max$ (L.) Merrill). Scientia Agricola, Piracicaba, v. 53, n. 1, p. 31-42, 1996.
DUTRA, A. S.; VIEIRA, R. D. Teste de condutividade elétrica para a avaliação do vigor de sementes de abobrinha. Revista Brasileira de Sementes, Brasília, v. 28, n. 2, p. 117-122, 2006.

FERREIRA, D. F. Sisvar: version 4. 2. Lavras: UFLA, 2003. $66 \mathrm{p}$.

FICK, G. L.; HIBBARD, R. P. A method for determining seed viability by electrical conductivity measurements. Michigan Academy Science Arts and Letters, Michigan, v. 5, n. 1, p. 95-103, 1925.

HAMMAN, B.; HALMAJAN, H.; EGLI, D. B. Single seed conductivity and seedling emergence in soybean. Seed Science and Technology, Zürich, v. 29, n. 3, p. 575586, 2001.

MARCONDES, M. C.; MIGLIORANZA, E.; FONSECA, I. C. B. Danos mecânicos e qualidade fisiológica de semente de soja colhida pelo sistema convencional e axial. Revista Brasileira de Sementes, Brasília, v. 27, n. 2, p. 125-129, 2005.

PANOBIANCO, M.; VIEIRA, R. D.; PERECIN, D. Electrical conductivity as an indicator of pea seed aging of stored at different temperatures. Scientia Agricola, Piracicaba, v. 64, n. 2, p. 119-124, 2007.

R DEVELOPMENT CORE TEAM. R: a language and environment for statistical computing. Vienna: Foundation for Statistical Computing, 2011. Disponível em: <http://www.R-project.org>. Acesso em: 27 mar. 2012.

SCHUCH, L. O. B.; KOLCHINSKI, E. M.; FINATTO, J. A. Qualidade fisiológica da semente e desempenho de plantas isoladas em soja. Revista Brasileira de Sementes, Brasília, v. 31, n. 1, p. 144-149, 2009.

SOUZA, L. A.; CARVALHO, M. L. M.; KATAOKA, V. Y.; OLIVEIRA, J. A. Teste de condutividade elétrica para avaliação da qualidade fisiológica de sementes de mamona. Revista Brasileira de Sementes, Brasília, v. 31, n. 1, p. 60-67, 2009.

STEERE, W. C.; LEVENGOOG, W. C.; BONDIE, J. M. An electronic analyser for evaluating seed germination and vigour. Seed Science and Technology, Zürich, v. 9, n. 2, p. 567-576, 1981.

VIEIRA, R. D.; PENARIOL, A. L.; PERECIN, D.; PANOBIANCO, M. Electrical conductivity and initial water content of soybean seeds. Pesquisa Agropecuária Brasileira, Brasília, v. 37, n. 9, p. 1333-1338, 2002.

WAIN-TASSI, A. L.; SANTOS, J. F. dos; PANIZZI, R. C.; VIEIRA, R. D. Seed-born pathogens and electrical conductivity of soybean seeds. Scientia Agricola, Piracicaba, v. 69, n. 1, p. 19-25, 2012. 